\title{
PERFORMANCE ANALYSIS OF 8 KW GRID- TIED SOLAR PHOTOVOLTAIC POWER PLANT IN DURBAN, SOUTH AFRICA
}

\author{
Abayomi Aduragba Adebiyi \\ Department of Electrical Power Engineering, Durban University of Technology, \\ Durban, South Africa \\ Ian Joseph Lazarus \\ Department of Physics, Durban University of Technology, Durban, South Africa \\ Akshay Kumar Saha \\ School of Engineering, Howard College, University of KwaZulu-Natal, \\ Durban, South Africa \\ Evans Eshiemogie Ojo \\ Department of Electrical Power Engineering, Durban University of Technology, \\ Durban, South Africa
}

\begin{abstract}
Results obtained from monitoring an outdoor experimental $8 \mathrm{~kW}$ distribution gridtied solar photovoltaic (SPV) system installed at Energy Technology Station known as KwaZulu-Natal Industrial Energy Efficient Training and Resource Centre (IEETRC) of Durban University of Technology, South Africa is presented in this study. The study was carried out to investigate and compare the system performance with similar installations in a few selected countries. Data were collected between January 2018 and December 2018 and computational analysis was completed with the aid of Simulink and MS-Excel. The evaluated monthly average daily and annual performance parameters of the SPV system - array yield, reference yield, final yield, system efficiency, inverter efficiency, capacity factor, and performance ratio - were discussed in term with the International Electrotechnical Commission (IEC) standard. A comparison of this study to other studies conducted in Dublin, Morocco, India, and Spain shows that this study final yield and performance ratio of $4.93 \mathrm{kWh} / \mathrm{kWp} /$ day and $87.1 \%$ is greater than what is reported in the extant literature.
\end{abstract}

Key words: Performance ratio, solar photovoltaic (SPV), annual energy generated, final yield, array yield, efficiency, capacity factor 
Cite this Article: Abayomi Aduragba Adebiyi, Ian Joseph Lazarus, Akshay Kumar Saha and Evans Eshiemogie Ojo, Performance Analysis of 8 KW Grid-Tied Solar Photovoltaic Power Plant in Durban, South Africa, International Journal of Advanced Research in Engineering and Technology, 10(4), 2019, pp. 140-153.

$\mathrm{http} / /$ iaeme.com/Home/issue/IJARET?Volume $=10 \&$ Issue $=4$

\section{INTRODUCTION}

The global goal to reduce climate change and environmental pollution caused by fossil fuel based energy sources have prompted the deployment of renewable energy resources like solar energy, wind power, hydro-power and biomass. The solar photovoltaic (SPV) and wind power generation have received more attention globally [1]. The SPV system could be installed in remote location (stand-alone) or integrated to the grid (grid-tied) [2]. Grid-tied SPV system uses the direct conversion of solar energy into electricity that is fed directly into the grid without battery storage. Like many other renewable energy alternatives, this option is generally carbonfree and as such does not emit greenhouse gasses during operation, as global warming and climate change are mostly caused by releasing carbon dioxide and other greenhouse gasses into the atmosphere. The solar irradiation level in South Africa is among the highest globally, with an average of 2500 hours of solar irradiation per annum ranging between 4.5 to $6.5 \mathrm{kWh} / \mathrm{m}^{2}$ per day [3]. The country different regions are well exposed to solar irradiation as shown in figure 1. The annual average 24-hour global solar irradiation for South Africa is about $220 \mathrm{~W} / \mathrm{m}^{2}$ compare to $150 \mathrm{~W} / \mathrm{m}^{2}$ in the USA and relatively $100 \mathrm{~W} / \mathrm{m}^{2}$ for Europe and United Kingdom [4] $[5]$.

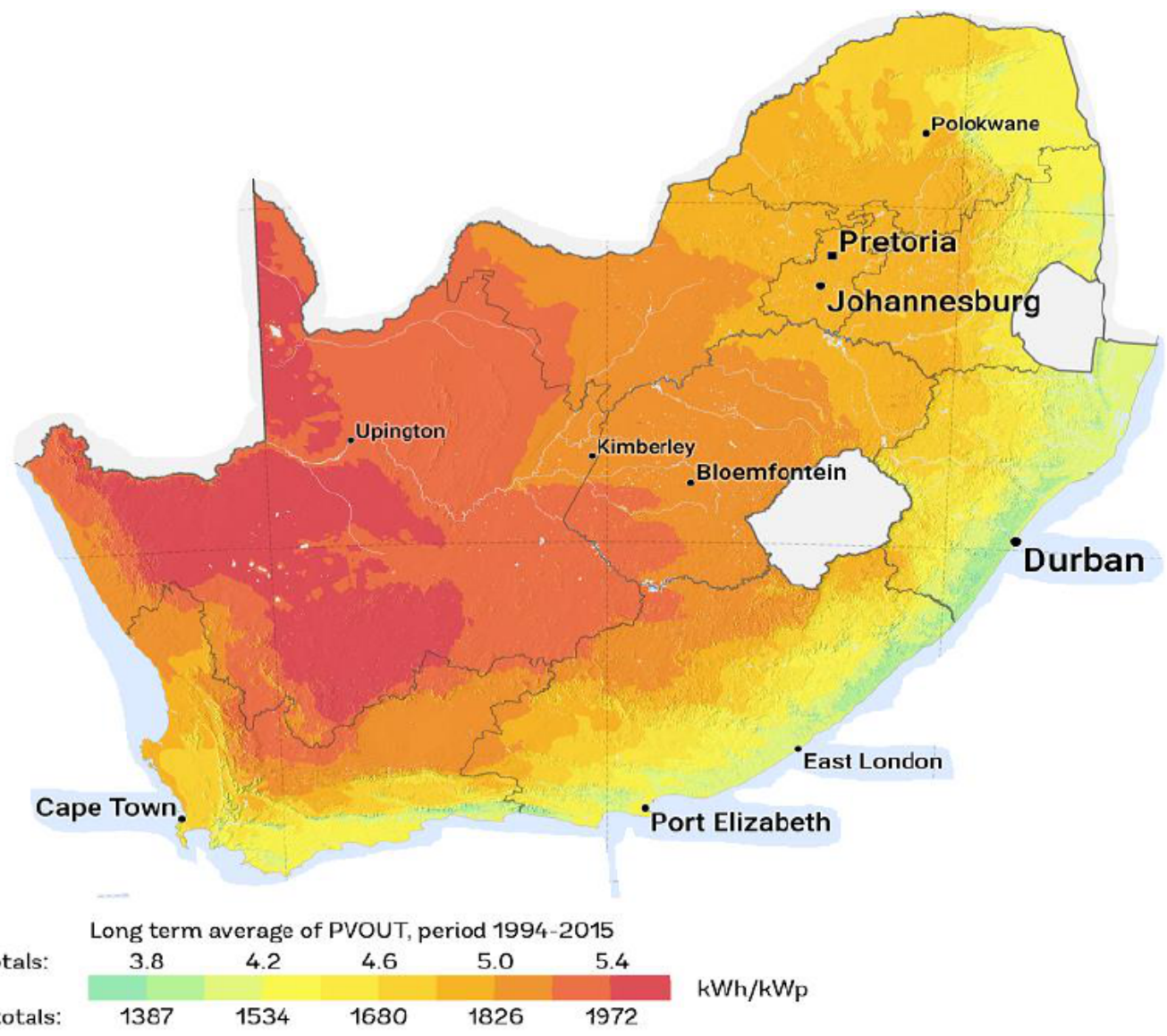

Figure 1 South Africa Global Horizontal Irradiation 
Due to rapidly rising electricity costs and growing awareness of global warming issues, in 2010, the South Africa government developed the Renewable Energy Source (RES) legal framework - Integrated Resource Plan (IRP), which deals with the concept of RES development. The IRP 2010 conceptualize programs to achieve 20 percent of renewable energy supply by 2030 [6]. Durban is the largest city on South Africa's East Coast province of KwaZulu-Natal (KZN), despite its high population density and energy consumption, no comprehensive study has been carried out to classify Durban's solar resource and grid-tied SPV system performance [7]. The basic requirement of any SPV power plant is to have an accurate estimate of its outdoor operating conditions performance. The information provided by a SPV module manufacturer is based on standard test condition (STC) of $1000 \mathrm{~W} / \mathrm{m}^{2}, 25^{\circ} \mathrm{C}$ and 1.5 Air Mass panel temperature. Due to the variation of environmental parameters, the results of STC may not agree with the actual operating conditions. Therefore, accurate performance data are required to install a SPV system at a specific location. Crystalline silicon and thin film SPV panels are the basic types of commercially available SPV panels [8].

Solar energy is playing a major role in the global energy mix due to improved technology and reduction in SPV system components costs leading to an increase in the global cumulative installed capacity from $1.4 \mathrm{GW}$ in 2000 to approximately $408.7 \mathrm{GW}$ in 2017 [5]. Table 1 shows the cumulative installed SPV capacity in selected countries in 2017, China has the highest capacity at 131 Gigawatt installed capacity. SPV systems performance analysis is the best way to determine the potential for producing solar power in an area. The objective of this study is to provide research results from a studied grid-tied SPV system at Industrial Energy Efficient Training and Resource Centre (IEETRC) of the Durban University of Technology, South Africa on the production of energy. It is believed that the results presented in this study will provide useful information on the actual performance of grid-tied SPV systems in this country to policymakers and interested individuals.

Table 1. SPV system installed capacity in 2017

\begin{tabular}{|c|c|}
\hline Country & SPV installed capacity (GW) \\
\hline Australia & 7.2 \\
\hline Belgium & 3.8 \\
\hline Canada & 2.9 \\
\hline China & 131 \\
\hline Germany & 1.75 \\
\hline India & 24.9 \\
\hline Japan & 49.1 \\
\hline South Africa & 0.15 \\
\hline South Korea & 5.7 \\
\hline Spain & 5.6 \\
\hline USA & 51.8 \\
\hline
\end{tabular}

\section{SYSTEM DESCRIPTION AND METHODOLOGY}

Radiometric data for an outdoor experimental $8 \mathrm{~kW}$ distribution grid-tied SPV system was recorded at the Energy Technology Station known as KwaZulu-Natal Industrial Energy Efficient Training and Resource Centre (IEETRC) of the Durban University of Technology, South Africa (-29.8579 N; 31.0276 E). The equipment housed at the IEETRC includes SOLYS2 sun tracker, pyranometer, SPV panels, DC/AC inverter, and temperature monitoring sensors. The pyranometer has a hihgh accuracy rate and a resolution of $1 \mathrm{~W} / \mathrm{m}^{2}$. The SOLYS2 operate from $\mathrm{AC}$ or $24 \mathrm{VDC}$ power. The $\mathrm{DC}$ power operating temperature varies between $-20^{\circ} \mathrm{C}$ to $50^{\circ} \mathrm{C}$ and could it could reach $-40^{\circ} \mathrm{C}$ on $\mathrm{AC}$ power using the standard internal heater. The pyranometer measures solar irradiation from all directions. SPV panels convert the solar 
irradiation into DC energy that is fed into an inverter unit which converts the DC energy to AC to feed the grid. In order to optimize the collection of input solar irradiation, all the SPV panels were mounted on the rooftop at a fixed $30^{\circ}$ tilt angle. At the SPV array installation shown in Figure 2, both the global horizontal solar irradiation and the wind speed data were logged and a computational analysis was completed with the aid of MS-Excel package. The evaluated monthly average daily and annual performance parameters of the SPV system - final yield, reference yield, array yield, system efficiency, inverter efficiency, capacity factor, and performance ratio - were discussed in term with the IEC standard. Comparative analysis of this system with other studies conducted in Dublin, Morocco, India, and Spain was conducted.

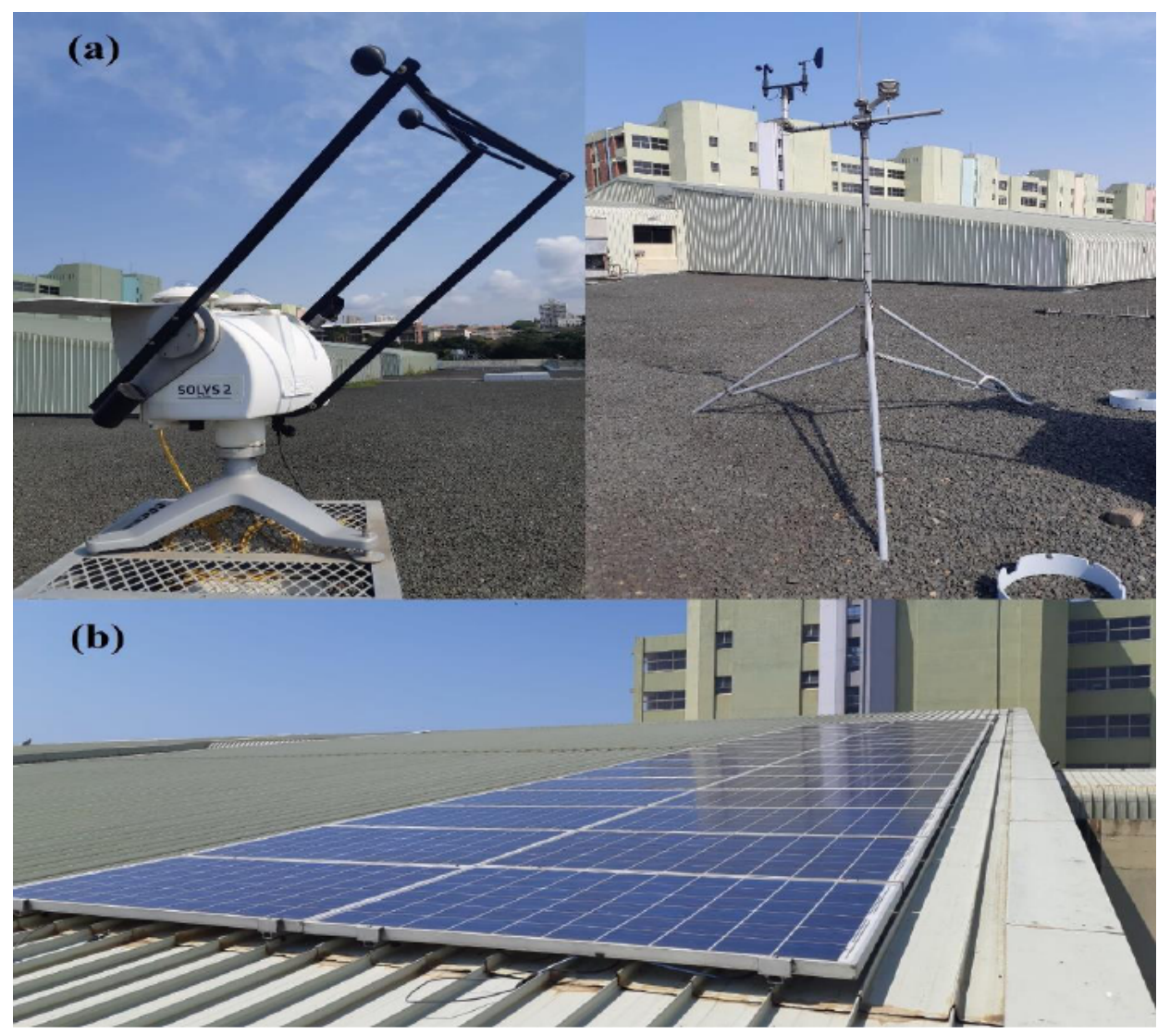

Figure 2 (a) Meteorological station installed at DUT (IEETRC) (b) Installed SPV array.

The SPV system consists of 30 poly-crystalline silicon panels linked in two string of 15 series-connected panels. The power rating of each panel is 220 Watt, the panels' specification is provided in Table 2 .

Table 2. Heckert Solar NeMo P (54) 220 specification

\begin{tabular}{|l|c|}
\hline$P_{\text {Max }}$ & $220 \mathrm{Wp}$ \\
\hline Short-circuit current & $8.62 \mathrm{~A}$ \\
\hline Open-cuitcuit voltage & $33.77 \mathrm{~V}$ \\
\hline Maximum Power Point Voltage & $27.54 \mathrm{~V}$ \\
\hline Maximum Power Point Current & $8.08 . \mathrm{A}$ \\
\hline Maximum System Voltage VDC & $1000 \mathrm{~V}$ \\
\hline Reverse current feed IR & $15,0 \mathrm{~A}$ \\
\hline Efficiency & $15.0 \%$ \\
\hline
\end{tabular}


A three phase Sunny Tripower 8000TL inverter was installed to convert the SPV array DC output to AC which was fed directly to the grid. It rated efficiency is $98.3 \%$ and peak AC power of $8000 \mathrm{~W}$. The inverter technical data is presented in Table 3.

Table 3 Sunny Tripower 8000TL Data [9]

\begin{tabular}{|l|c|}
\hline \multicolumn{2}{|c|}{ Input (DC) } \\
\hline Maximum generator power & $13500 \mathrm{Wp}$ \\
\hline Maximum input voltage & $1000 \mathrm{~V}$ \\
\hline MPP voltage range & $330 \mathrm{~V}$ to $800 \mathrm{~V}$ \\
\hline Minimum input voltage & $150 \mathrm{~V} / 188 \mathrm{~V}$ \\
\hline Maximum input current $15 \mathrm{~A}$ \\
\hline Maximum short-circuit current input & $2 / \mathrm{A}: 2$ \\
\hline \multicolumn{2}{|c|}{ Output (AC) } \\
\hline Rated power (at 230 V, 50 Hz) & $8000 \mathrm{~W}$ \\
\hline Maximum AC apparent power & $8000 \mathrm{VA}$ \\
\hline Nominal AC voltage & $230 / 400 \mathrm{~V}$ \\
\hline AC grid frequency & $50 \mathrm{~Hz} \pm 5 \mathrm{~Hz}$ \\
\hline Rated power frequency & $50 \mathrm{~Hz} / 230 \mathrm{~V}$ \\
\hline Maximum output current & $11.6 \mathrm{~A}$ \\
\hline Power Factor at rated current & 0.8 leading to 0.8 lagging \\
\hline Efficiency & $98 \%$ \\
\hline
\end{tabular}

\section{MONITORED INPUT RESULTS}

The monthly average daily horizontal solar radiation and the ambient temperature are presented in figure 2. This indicates the expected seasonal trend for the coastal region of Durban, with the daily solar irradiation diffuse monthly average falling over the winter season and then rising towards the summer season. The monthly average daily irradiance varies from the least value of $110 \mathrm{kWh} / \mathrm{m}^{2}$ in June to $190 \mathrm{kWh} / \mathrm{m}^{2}$ in January. In January, February and March, maximum monthly average daily temperatures of $26^{\circ} \mathrm{C}, 25^{\circ} \mathrm{C}$ and $24^{\circ} \mathrm{C}$ were recorded respectively while the lowest monthly average daily temperatures being $15^{\circ} \mathrm{C}$ and $16^{\circ} \mathrm{C}$ were recorded in June and July respectively.

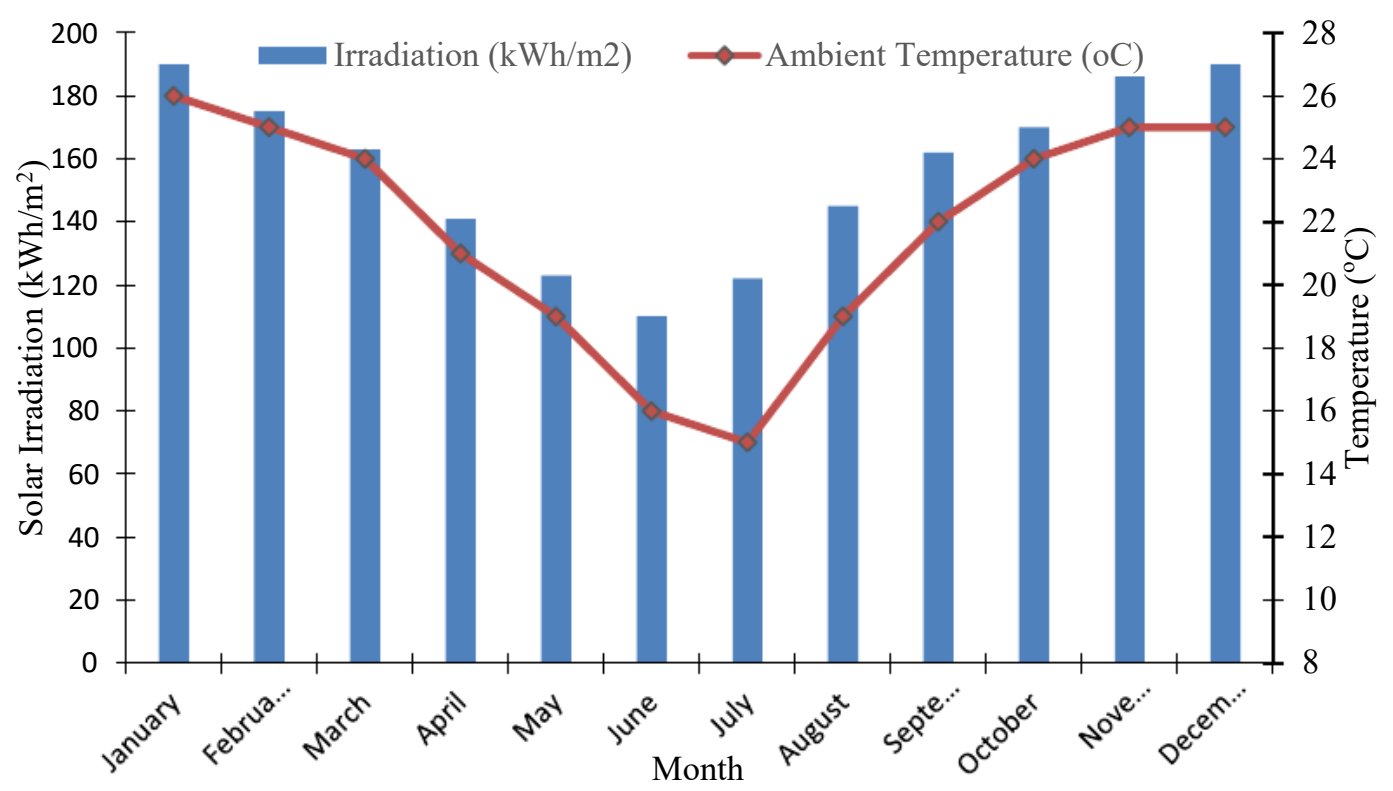

Figure 3 Monthly average global horizontal solar irradiation and temperature. 
As shown in figure 3, the measured monthly average daily ambient temperature $\left(T_{a}\right)$ and module temperature $\left(\mathrm{T}_{\mathrm{m}}\right)$ vary throughout the monitored period due to the generation of thermal losses obviously occurring on power generation. The temperature of the SPV module was always found higher than the ambient temperature. It was observed that the ambient temperature varies from $15.3^{\circ} \mathrm{C}$ to $29.4^{\circ} \mathrm{C}$ over the measured period. Figures 4 and 5 represent the recorded data file for a cloudy and sunny day.

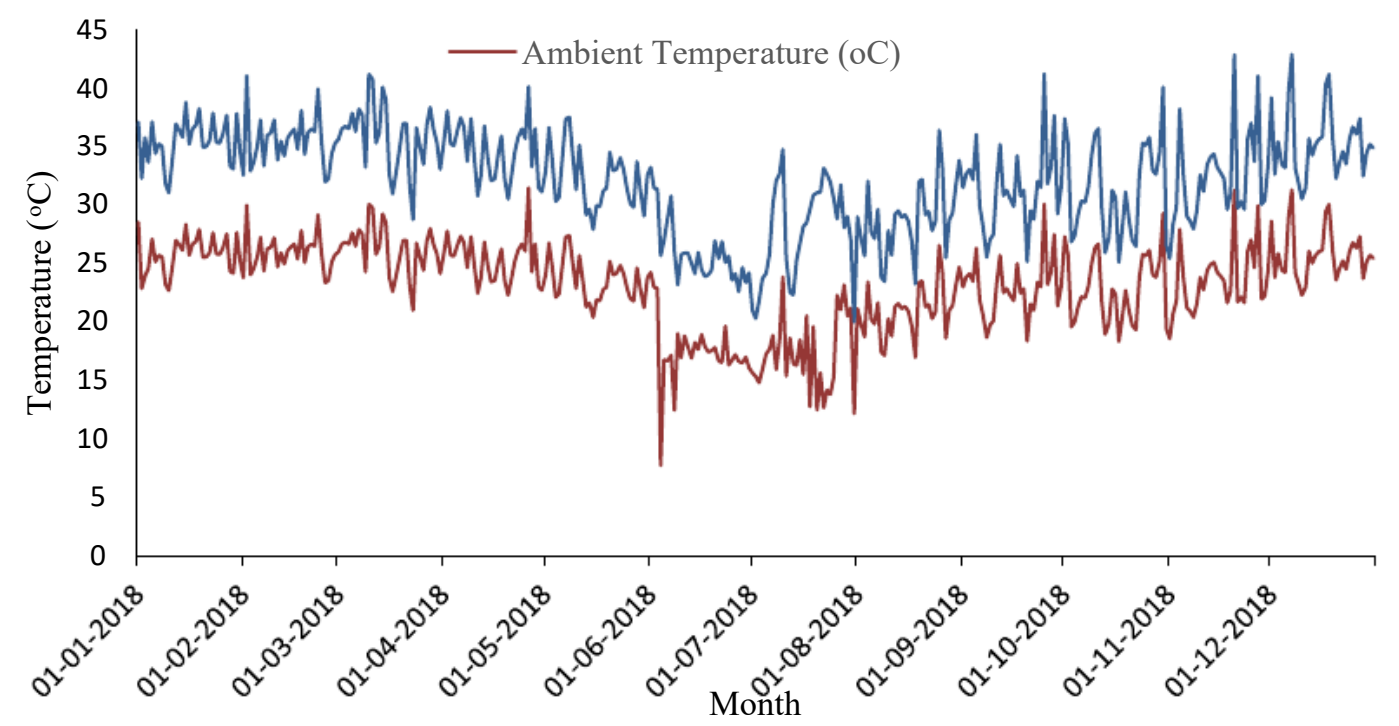

Figure 4 Monthly average daily ambient temperature (Ta) and module temperature (Tm).

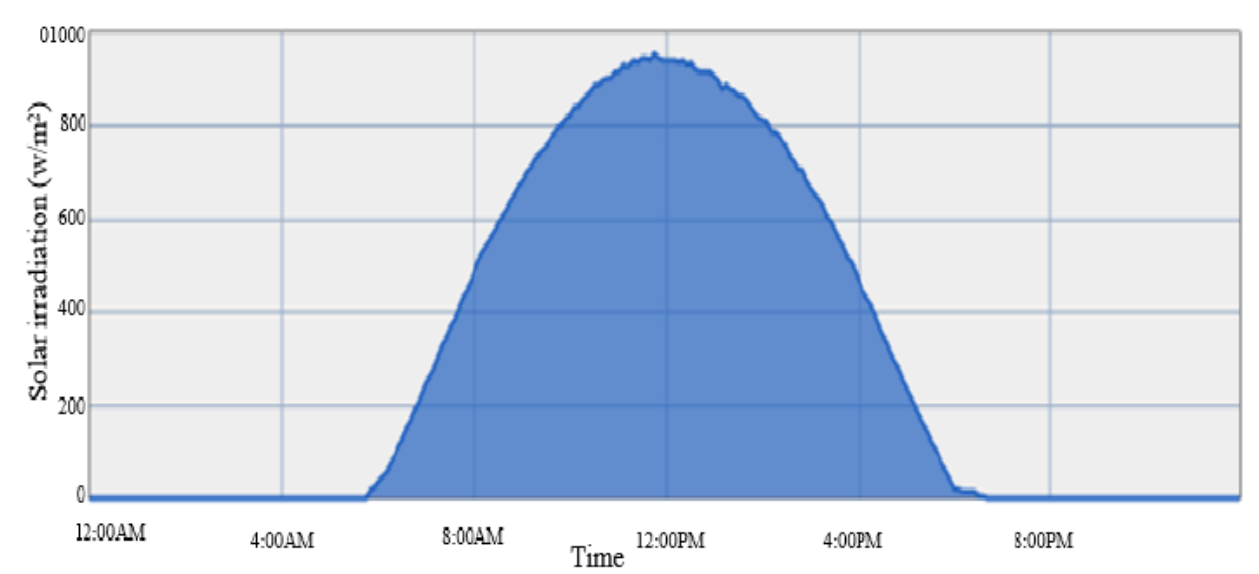

Figure 5 Irradiance plots for a sunny day in summer

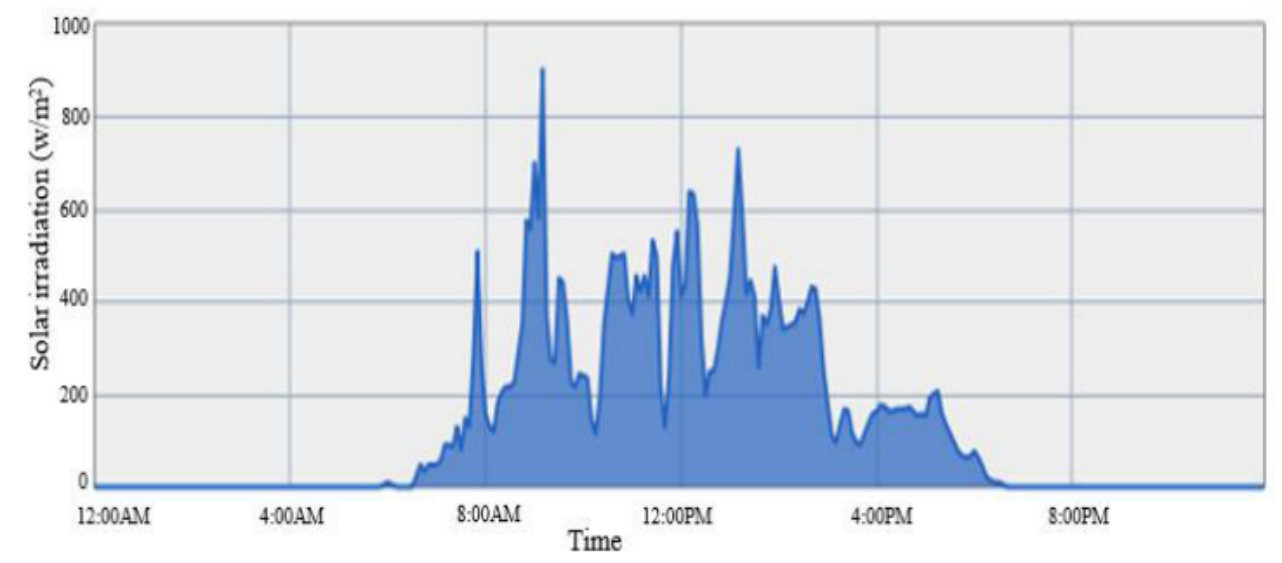

Figure 6 Irradiance plots for a cloudy day in winter. 


\section{SYSTEM ANALYSIS}

In this paper, performance parameters established by the International Energy Agency (IEA) Photovoltaic Power Systems Programme Task 2 and defined in International Electrotechnical Commission (IEC) 61724-1:2017 were considered [10]. Field data of the $8 \mathrm{~kW}$ rooftop gridtied SPV power plant was analyzed for the plant annual energy generated, final yield, reference yield, array yield, system loss, system efficiency, inverter efficiency, capacity factor unit, and performance ratio in the year 2018 and the actual measured and calculated performance parameters were compared with results obtained from extant literature.

\subsection{Annual Energy Generated}

The annual output energy generated by the SPV system is defined by the amount of DC and $\mathrm{AC}$ power generated over a given time period. The total energy produced hourly, daily and monthly can be evaluated by the equations (1) to (4) [11].

\subsubsection{Energy generated by the SPV array $\left(E_{d c}\right)$}

The SPV array total daily and monthly DC energy output generated is given by:

$$
\begin{gathered}
E_{d c, d}=\sum_{t=1}^{t=T_{r p}} V_{d c} * I_{d c} * T_{r} \\
E_{d c, m}=\sum_{d=1}^{N} E_{d c, d}
\end{gathered}
$$

Where $\mathrm{E}_{\mathrm{dc}}=$ Array DC energy output,

$\mathrm{T}_{\mathrm{r}}=$ the recording time interval,

$\mathrm{T}_{\mathrm{rp}}=$ the recording period and

$\mathrm{N}=$ number of days plant operate in a month

\subsubsection{Energy output fed to the grid (Eac)}

The total daily and monthly $\mathrm{AC}$ energy output $\mathrm{E}_{\mathrm{AC}, \mathrm{m}}(\mathrm{kW} / \mathrm{h})$ measured across the inverter output terminal are defined as follow [12]:

$$
\begin{gathered}
E_{a c, d}=\sum_{t=1}^{t=T_{r p}} V_{a c} * I_{a c} * T_{r} \\
E_{a c, m}=\sum_{d=1}^{N} E_{a c, d}
\end{gathered}
$$

Where $\mathrm{E}_{\mathrm{ac}}=\mathrm{AC}$ energy output to grid, $\mathrm{N}=$ number of days plant operate in a month. 


\subsection{Array Yield $\left(\mathbf{Y}_{\mathrm{A}}\right)$}

The array yield is the time it takes for the SPV system to operate at the $E_{\mathrm{dc}}$ generating nominal power [13]. It is, therefore, the ratio of the daily or monthly average DC energy generated by the SPV system to the nominal SPV system power. The daily and monthly array yield is obtained using Equations (5) and (6), as shown below.

$$
\begin{gathered}
Y_{A, d}=\frac{E_{D C, d}}{P_{P V, \text { rated }}} \\
Y_{A, m}=\frac{1}{N} \sum_{d=1}^{N} Y_{A, d}
\end{gathered}
$$

Where $\mathrm{Y}_{\mathrm{A}, \mathrm{d}}=$ Daily array yield,

$\mathrm{Y}_{\mathrm{A}, \mathrm{m}}=$ Monthly array yield,

$\mathrm{N}=$ number of days plant operate in a month.

\subsection{Final Yield $\left(\mathbf{Y}_{\mathrm{F}}\right)$}

The final yield is the ratio of system's daily, monthly or annual total AC energy output $(\mathrm{kWh})$ to the installed SPV array's rated power at $1 \mathrm{~kW} / \mathrm{m}^{2}$ solar irradiation and $25^{\circ} \mathrm{C}$ module temperature. It is a performance index that allows similar SPV systems comparison in a specific geographic area. It depends on the mounting type, the inclination of a roof, and also the plant location [14]. The final annual yield is given as:

$$
\begin{gathered}
Y_{F, d}=\frac{E_{A C, d}}{P_{P V, \text { rated }}} \\
Y_{F, m}=\frac{1}{N} \sum_{d=1}^{N} E_{A C, d}
\end{gathered}
$$

Where $Y_{F, d}=$ Daily final yield,

$\mathrm{Y}_{\mathrm{A}, \mathrm{m}}=$ Monthly average daily final yield,

$\mathrm{N}=$ number of days plant operate in a month.

\subsection{Reference Yield $\left(\mathbf{Y}_{R}\right)$}

The reference yield is the ratio of total daily horizontal solar irradiance $H_{t}\left(\mathrm{~kW} / \mathrm{m}^{2}\right)$ to the reference solar irradiation $\left(\mathrm{G}_{\mathrm{i}-\mathrm{ref}}\right)$. This yield represents the number of peak sun-hour per day $(\mathrm{h} / \mathrm{d})$ expressed in equation (9).

$$
Y_{R}=\frac{H_{t}\left(k W h / m^{2}\right)}{G_{i-r e f}\left(\frac{k W}{m^{2}}-d a y\right)}
$$

Where $\mathrm{G}_{\mathrm{i} \text {-ref }}=1 \mathrm{~kW} / \mathrm{m}^{2}$ 


\subsection{Efficiency}

The grid-tied SPV system components efficiencies are SPV panel efficiency $\left(\eta_{\mathrm{SPV}}\right)$, inverter efficiency ( $\left.\eta_{\text {inv }}\right)$ and the general system efficiency $\left(\eta_{\text {sys }}\right)[15]$. Basically, these efficiencies can be calculated instantaneously, per hour, per day, monthly and annually. The SPV panel efficiency is based on the DC energy output while the system efficiency is a function of the AC power output. The instantaneous SPV panel efficiency is calculated as:

$$
\eta_{P V}=\frac{E_{D C}}{\left(H_{t} * A_{a}\right)}
$$

where $E_{D C}=$ SPV array output energy,

$\mathrm{H}_{\mathrm{t}}=$ Global solar irradiation,

$\mathrm{A}_{\mathrm{a}}=$ Area of SPV array.

The monthly average SPV array efficiency is determined by Equation (10):

$$
\eta_{P V}=\frac{E_{D C, d}}{\left(H_{t} * A_{a}\right)} * 100 \%
$$

where $\mathrm{E}_{\mathrm{DC}, \mathrm{d}}=$ Total daily DC output energy.

\subsubsection{Inverter efficiency}

The instantaneous inverter efficiency $\left(\eta_{\text {inv }}\right)$ is given below:

$$
\eta_{i n v}=\frac{E_{A C}}{E_{D C}}
$$

where $\mathrm{E}_{\mathrm{AC}}=$ Output energy of the inverter and $\mathrm{E}_{\mathrm{DC}}=$ Energy at the input of the inverter.

The monthly inverter efficiency $\left(\eta_{\text {inv,m }}\right)$ considered over the data recording period is calculated as follows:

$$
\eta_{i n v, m}=\frac{E_{A C, d}}{E_{D C, d}} * 100 \%
$$

\subsubsection{System efficiency ( $\eta$ sys)}

The efficiency of the entire SPV system is defined as the ratio of the energy generated $\left(E_{A C, d}\right)$ to the global horizontal solar irradiation $\left(\mathrm{H}_{t}\right)$ at the SPV array area $\left(\mathrm{A}_{\mathrm{a}}\right)$. By applying equation (13) the system efficiency was calculated.

$$
\eta_{s y s}=\frac{E_{A C, d}}{\left(H_{t} * A_{a}\right)} * 100 \%
$$

\subsection{Performance Ratio}

The performance ratio (PR) is the quality factor of a SPV plant that shows the magnitude of the plant output energy in percent. The performance ratio defines the relationship between the SPV plant's final yield and the reference yield. It is the quantity of energy fed into the grid after deduction of energy losses and operational energy consumption [13].

$$
P R=Y_{F}-Y_{R}
$$




\subsection{Capacity Factor}

The capacity factor (CF) of a SPV power plant is the ratio of the annual AC energy output to the AC energy generated by the SPV system when it operates at full rated power (PSPV, rated) throughout the same period. The SPV system's annual capacity factor is determined by the following equation:

$$
C F=\frac{E_{A C}}{P_{P V, \text { rated }} * 8,760}
$$

The performance parameters mentioned above provide the overall system performance in terms of energy production, meteorological resource, and overall system loss effect.

\section{RESULTS AND DISCUSSION}

The output energy generated by the SPV system was measured at the DC/AC inverter at 5 minutes intervals. Figure 7 shows the total monthly energy generated by the SPV system, which ranged from $220.6 \mathrm{kWh}$ in June to $415.7 \mathrm{kWh}$ in January during the monitored period. The SPV system generated a total annual energy yield of $16.178 \mathrm{MWh}$ as measured by the inverter.

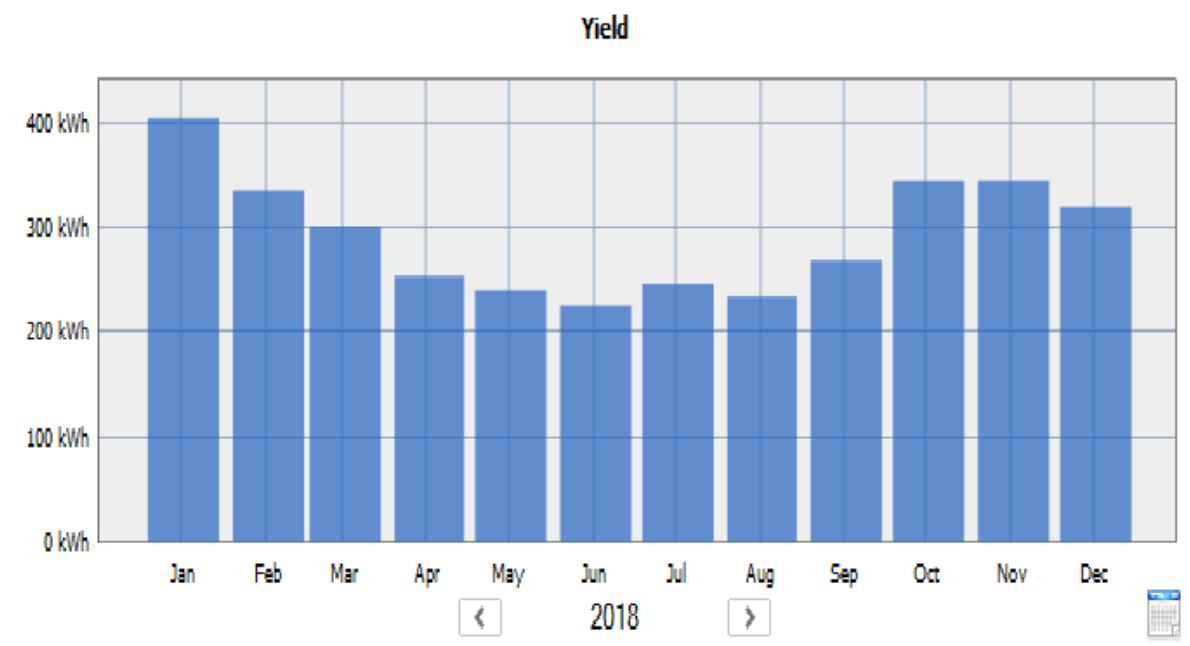

Figure 7 Total monthly energy generated by the SPV system.

The SPV system monthly average daily final yield, reference yield, and array yield monitored within January to December 2018 is presented in figure 8. The minimum and maximum values recorded vary between June and January from $3.59-5.84 \mathrm{kWh} / \mathrm{kWp} /$ day, $4.15-7.02 \mathrm{kWh} / \mathrm{kWp} /$ day, and $3.33-6.2 \mathrm{kWh} / \mathrm{kWp} /$ day for the final, reference and array yields respectively. This is attributed to the fact that the minimum average horizontal solar irradiation was received in June at $3.68 \mathrm{kWh} / \mathrm{m}^{2} /$ day and maximum $6.13 \mathrm{kWh} / \mathrm{m}^{2} /$ day in January with an annual average value of $4.52 \mathrm{kWh} / \mathrm{m}^{2} /$ day. From figure 8 , it can be seen that the system yields relate in variation over the monitored period. It is found that they are directly proportional to the horizontal solar irradiation 


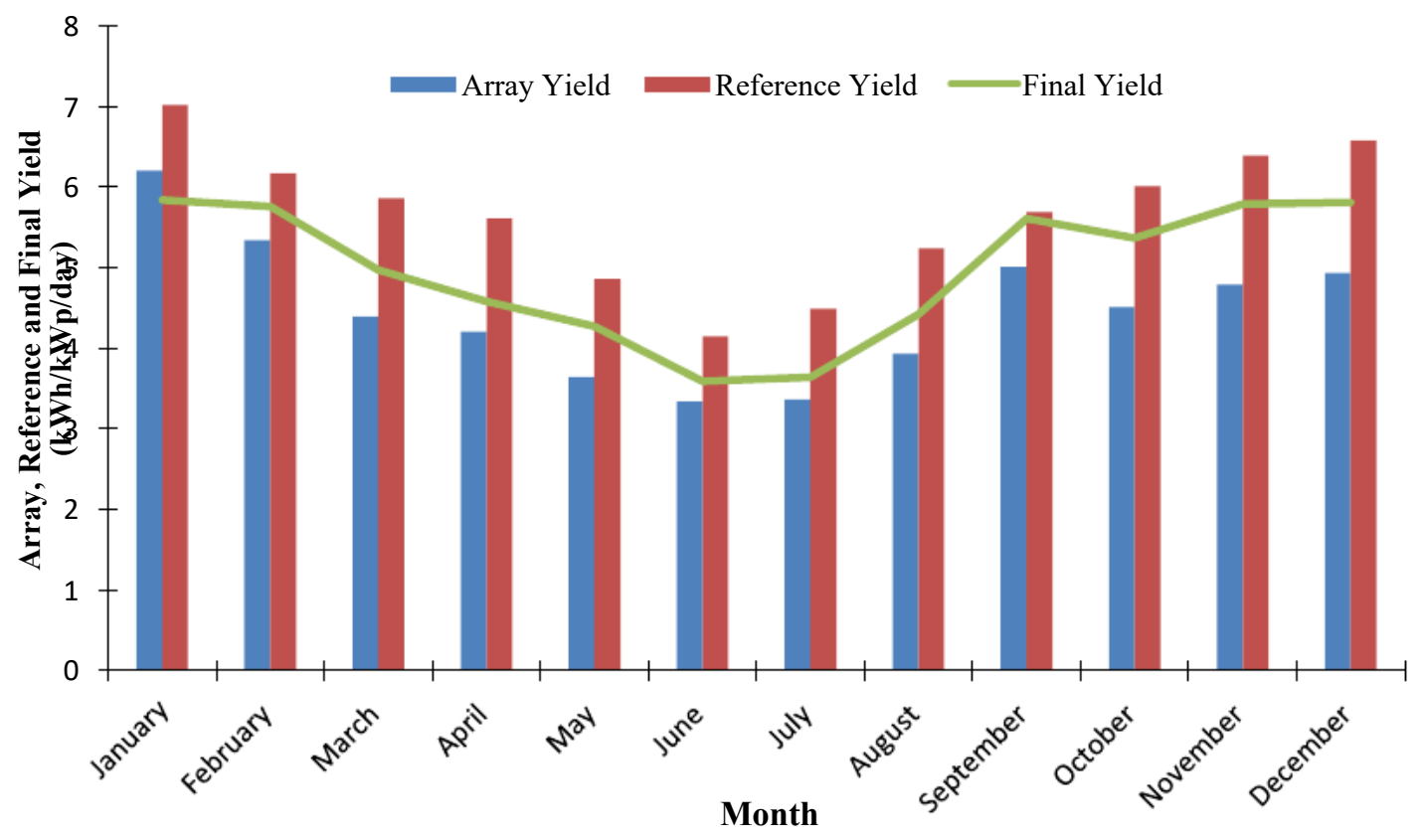

Figure 8 Monthly average daily SPV system's array yield, reference yield and final yield over the monitored period.

Figure 9 shows variations in the monthly average daily performance ratio and the capacity factor of the SPV system over the period monitored. The performance ratio ranged from $81.4 \%$ in July to $93.7 \%$ in February and the average annual performance ratio was $87.1 \%$. The monthly average daily capacity factor ranged from 17.1 percent in December to 20.1 percent in June with a 10.1 percent annual average. The capacity factor varies depending on the final yield that usually vary alongside the generated AC energy. The maximum value of the average monthly capacity factor was 19.97 percent in January, where the final yield is also high at 5.84 $\left(\mathrm{kWh} / \mathrm{kW}_{\mathrm{p}} /\right.$ day $)$ and the lowest value was 16.57 percent in June, where the final yield was comparatively low at 3.59 ( $\mathrm{kWh} / \mathrm{kWp} /$ day).

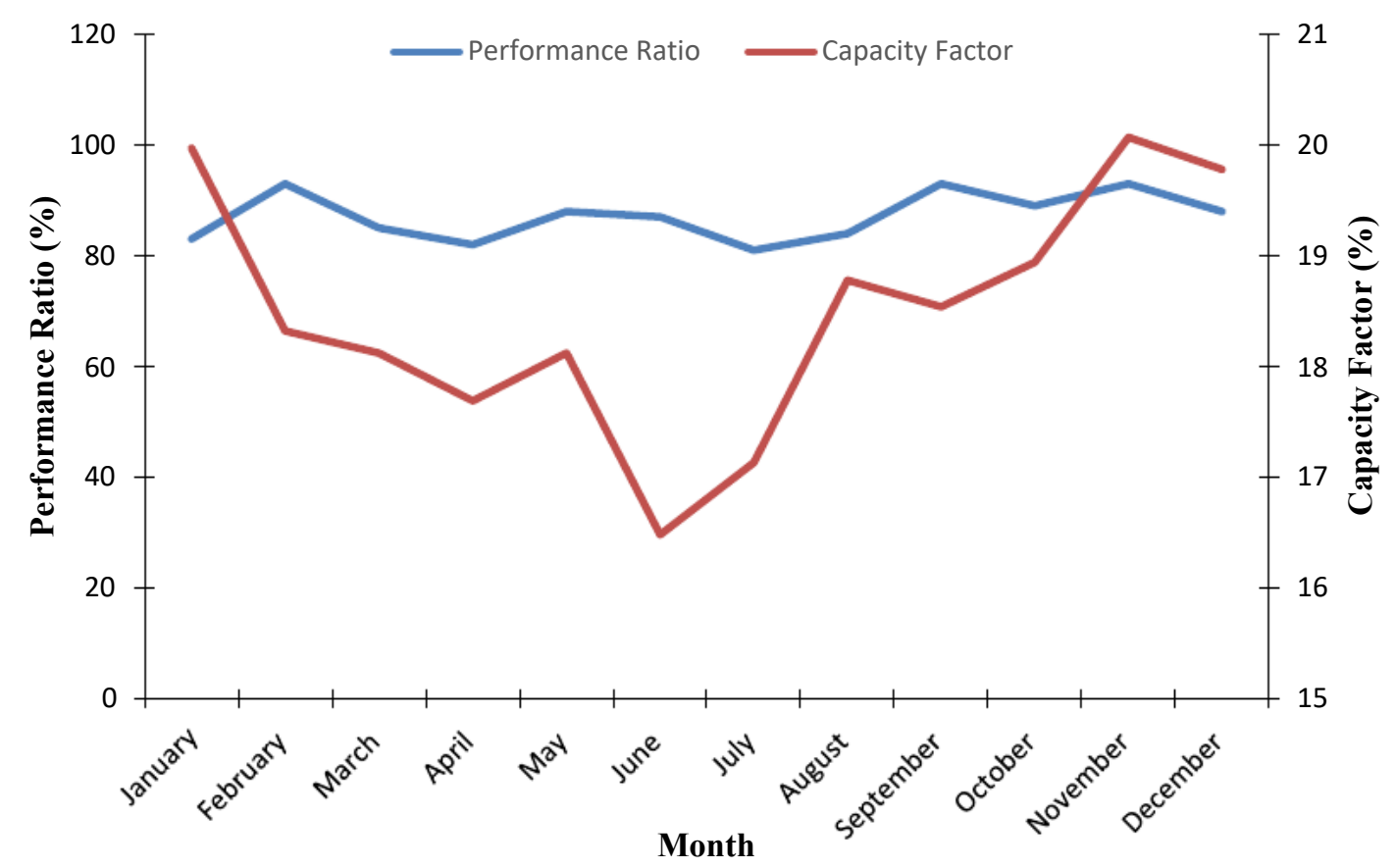

Figure 9 Monthly average daily performance ratio and capacity factor. 
The annual average of the SPV panel efficiency, system efficiency, and inverter efficiency were found to be $13.15 \%, 12.06 \%$ and $96.33 \%$ respectively as illustrated in figure 10 . The seasonal monthly average inverter efficiency for the summer and winter season was found to be $96.74 \%$ and $95.76 \%$ as a result of the average horizontal solar irradiation which was 6.16 $\mathrm{kWh} / \mathrm{m}^{2} /$ day for summer and $5.37 \mathrm{kWh} / \mathrm{m}^{2} /$ day for winter respectively.

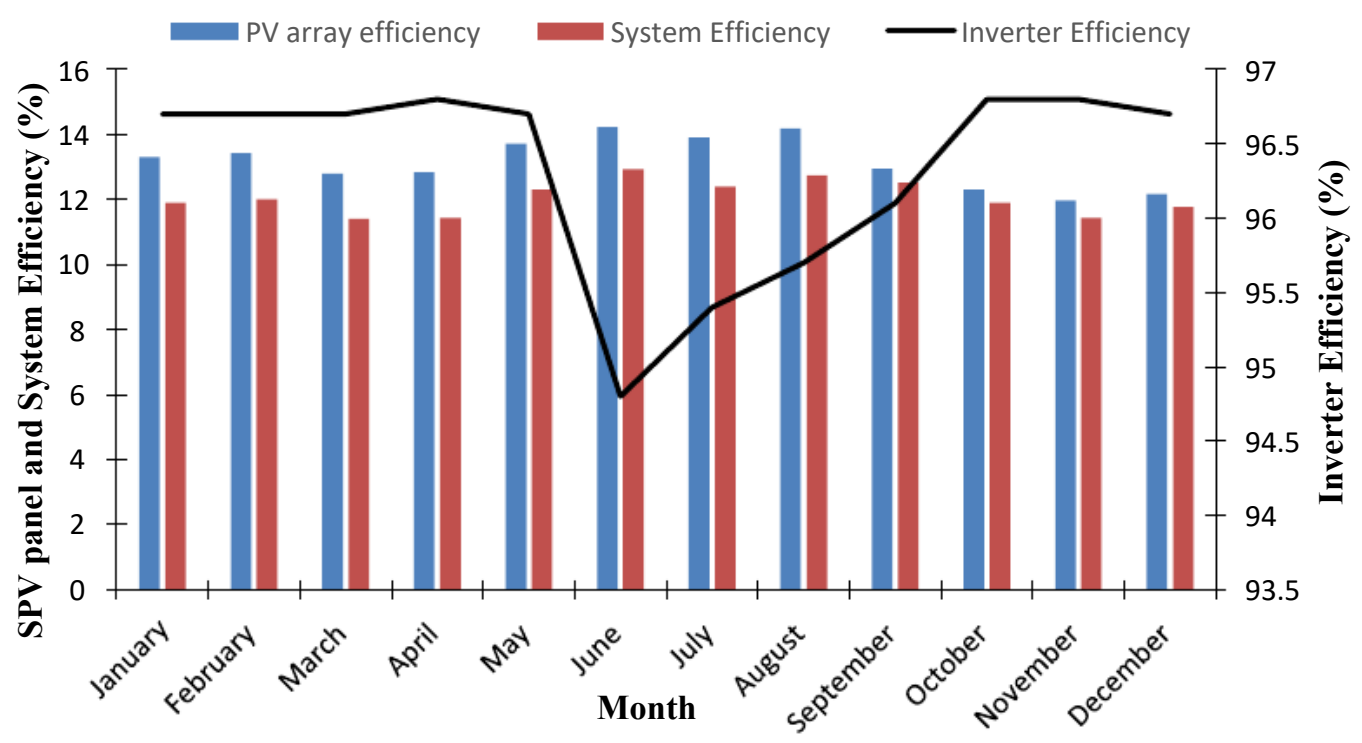

Figure 10. Monthly daily average array efficiency, system efficiency, and inverter efficiency

\section{PERFORMANCE COMPARISON}

Comparative analysis of performance parameters of this study with some of the existing gridtied SPV system reported in literature is presented in Table 4. The annual daily final yield are: Dublin, Ireland, $2.47 \mathrm{kWh} / \mathrm{kWp}$ /day; Tangier, Morocco, $4.45 \mathrm{kWh} / \mathrm{kWp} /$ day; Eastern India, $3.67 \mathrm{kWh} / \mathrm{kWp} /$ day; Bhopal, India, $3.36 \mathrm{kWh} / \mathrm{kWp} /$ day; Jaén, Spain, $3.26 \mathrm{kWh} / \mathrm{kWp} /$ day and $4.93 \mathrm{kWh} / \mathrm{kWp} /$ day for this study which is greater than those reported in Morocco, India, Northern Ireland and Spain. Similarly, this study obtained the highest performance ratio.

Table 4. Performance comparison of different grid-tied SPV system in literature.

\begin{tabular}{lcccccccc}
\hline Location & $\begin{array}{c}\text { Installed } \\
\text { Capacity } \\
(\mathbf{k W})\end{array}$ & $\begin{array}{c}\text { Energy Output } \\
(\mathbf{k W h} / \mathbf{k W})\end{array}$ & $\begin{array}{c}\text { Final Yield } \\
\mathbf{( k W} \mathbf{h} / \\
\mathbf{k W p}-\mathbf{d a y})\end{array}$ & $\begin{array}{c}\text { SPV Panel } \\
\text { Efficiency } \\
(\mathbf{\%})\end{array}$ & $\begin{array}{c}\text { System } \\
\text { Efficiency } \\
(\mathbf{\%})\end{array}$ & $\begin{array}{c}\text { Inverter } \\
\text { Efficiency } \\
\mathbf{( \% )}\end{array}$ & $\begin{array}{c}\text { PR } \\
\mathbf{( \% )}\end{array}$ & References \\
\hline $\begin{array}{l}\text { Dublin, } \\
\text { Ireland }\end{array}$ & 1.72 & 885.1 & 2.47 & 14.9 & 12.6 & 89.2 & 81.5 & {$[13]$} \\
\hline $\begin{array}{l}\text { Durban, } \\
\text { South } \\
\text { Africa }\end{array}$ & $\mathbf{8}$ & $\mathbf{1 6 1 7 8}$ & $\mathbf{4 . 9 3}$ & $\mathbf{1 3 . 2}$ & $\mathbf{1 2 . 1}$ & $\mathbf{9 6 . 3}$ & $\mathbf{8 7 . 1}$ & $\begin{array}{c}\text { Present } \\
\text { study }\end{array}$ \\
\hline $\begin{array}{l}\text { Düzce } \\
\text { Province } \\
\text { Turkey }\end{array}$ & 2.64 & 3141.15 & - & 11.36 & 11.4 & 90.7 & 81 & {$[16]$} \\
$\begin{array}{l}\text { Tangier, } \\
\text { Morocco }\end{array}$ & 5 & 6411.3 & 4.45 & 12.38 & 11.99 & 96.7 & 79 & {$[17]$} \\
\hline $\begin{array}{l}\text { Eastern } \\
\text { India }\end{array}$ & 11.2 & - & 3.67 & 13.42 & - & 89.83 & 78 & {$[18]$} \\
\hline $\begin{array}{l}\text { Bhopal, } \\
\text { India }\end{array}$ & 110 & 163100 & 3.36 & - & - & - & 71.6 & {$[19]$} \\
\hline Jaén, Spain & 200 & 892.1 & 3.26 & 8.9 & 7.8 & 88.1 & 62.7 & {$[20]$} \\
\hline
\end{tabular}




\section{CONCLUSIONS}

An $8 \mathrm{~kW}$ grid-tied SPV system installed in Industrial Energy Efficient Training and Resource Centre (IEETRC) of Durban University of Technology, South Africa was monitored between January 2018 and December 2018 and its performance parameters were evaluated on a monthly and annual basis. Data recorded during the monitored period showed that with increased solar irradiation, the output power of the SPV plant increases linearly. The annual average final yield and reference yield were $4.93 \mathrm{kWh} / \mathrm{kWp}$ /day and $5.59 \mathrm{kWh} / \mathrm{kWp}$ /day while the annual average of the SPV panel efficiency, system efficiency, and inverter efficiency was found to be $13.15 \%$, $12.06 \%$ and $96.33 \%$ respectively The performance ratio ranged from $81.4 \%$ in July to $93.7 \%$ in February and the average annual Performance Ratio was $87.1 \%$. Performance ratio is a key indicator of SPV system effectiveness therefore, performance ratio above $80 \%$ is always desired. The evaluated annual performance ratio obtained confirms the vast solar potential suitable for solar power generation in KwaZulu-Natal Province of South Africa. A comparison of this study to other studies conducted in Dublin, Morocco, India, and Spain shows that this study final yield and performance ratio of $4.93 \mathrm{kWh} / \mathrm{kWp} /$ day and $87.1 \%$ is higher than what is reported in the extant literature.

\section{ACKNOWLEDGMENTS}

The South Africa National Research Foundation (NRF) supported this study under research grant number UID 118708 and the management of IEETRC of the Durban University of Technology, South Africa provided all the experimental infrastructures.

\section{REFERENCES}

[1] A. Adebiyi, I. Lazarus, A. Saha, and E. Ojo, "Performance analysis of PV panels connected in various orientations under different climate conditions," in Proceedings of the 5th Southern African Solar Energy Conference (SASEC 2018), Durban, South Africa, 2018, pp. 46-51: Mechanical and Mechatronic Engineering, Stellenbosch University.

[2] R. Rawat, S. Kaushik, R. J. R. Lamba, and S. E. Reviews, "A review on modeling, design methodology and size optimization of photovoltaic based water pumping, standalone and grid connected system," Renewable and Sustainable Energy Reviews, vol. 57, pp. 15061519, 2016.

[3] T. V. Kumar, "Smart Metropolitan Regional Development: Economic and Spatial Design Strategies," in Smart Metropolitan Regional Development: Springer, 2019, pp. 3-97.

[4] I. Ibp, Slovakia Investment and Business Guide Volume 1 Strategic and Practical Information. Int'1 Business Publications, 2015.

[5] A. JÄGER-WALDAU, "PV Status Report 2018," European Commission, Joint Research Centre (JRC), Luxembourg,2018, Available: https://ec.europa.eu/jrc.

[6] W. L. Fritz, "Challenges of tying small scale renewable energy systems to the grid in South Africa," in Proceedings of the 21st Domestic Use of Energy Conference, 2013, pp. 1-5: IEEE.

[7] [7] E. Zawilska and M. Brooks, "Solar energy measurement on the South African east coast," in World Renewable Energy Congress, Linköping; Sweden, 2011, no. 057, pp. 36863693: Linköping University Electronic Press.

[8] M. A. Bashir, H. M. Ali, M. Ali, and A. M. J. T. S. Siddiqui, "An experimental investigation of performance of photovoltaic modules in Pakistan," Thermal Science, vol. 19, no. Suppl 2, pp. S525-S534, 2015.

[9] "SMA Tripower 8000TL datasheet," ed, 2019, pp. 1-6. 
[10] I. E. Agency, "Photovoltaic system performance monitoring - Guidelines for measurement, data exchange and analysis," ed, 2017, pp. 1-118.

[11] D. Okello, E. Van Dyk, and F. Vorster, "Analysis of measured and simulated performance data of a $3.2 \mathrm{kWp}$ grid-connected PV system in Port Elizabeth, South Africa," Energy Conversion and Management, vol. 100, pp. 10-15, 2015.

[12] A. Necaibia et al., "Analytical assessment of the outdoor performance and efficiency of grid-tied photovoltaic system under hot dry climate in the south of Algeria," Energy Conversion and Management, vol. 171, pp. 778-786, 2018.

[13] L. Ayompe, A. Duffy, S. McCormack, and M. Conlon, "Measured performance of a 1.72 $\mathrm{kW}$ rooftop grid connected photovoltaic system in Ireland," Energy Conversion and Management, vol. 52, no. 2, pp. 816-825, 2011.

[14] V. Sharma and S. J. E. Chandel, "Performance analysis of a $190 \mathrm{kWp}$ grid interactive solar photovoltaic power plant in India," Energy, vol. 55, pp. 476-485, 2013.

[15] M. S. Adaramola and E. E. Vågnes, "Preliminary assessment of a small-scale rooftop PVgrid tied in Norwegian climatic conditions," Energy Conversion and Management, vol. 90, pp. 458-465, 2015.

[16] E. Elibol, Ö. T. Özmen, N. Tutkun, and O. Köysal, "Outdoor performance analysis of different PV panel types," Renewable Sustainable Energy Reviews, vol. 67, pp. 651-661, 2017.

[17] K. Attari, A. Elyaakoubi, and A. J. E. R. Asselman, "Performance analysis and investigation of a grid-connected photovoltaic installation in Morocco," Energy Reports, vol. 2, pp. 261266, 2016.

[18] R. Sharma and S. J. E. R. Goel, "Performance analysis of a $11.2 \mathrm{kWp}$ roof top gridconnected PV system in Eastern India," Energy Reports, vol. 3, pp. 76-84, 2017.

[19] A. K. Shukla, K. Sudhakar, and P. J. E. R. Baredar, "Simulation and performance analysis of $110 \mathrm{kWp}$ grid-connected photovoltaic system for residential building in India: A comparative analysis of various PV technology," Energy Reports, vol. 2, pp. 82-88, 2016.

[20] M. Drif et al., "Univer Project. A grid connected photovoltaic system of 200kWp at Jaén University. Overview and performance analysis," Solar Energy Materials and Solar Cells, vol. 91, no. 8, pp. 670-683, 2007.

[21] Rajveer Singh, Manish Kumar, Haroon Ashfaq, An Integrated Solar Photovoltaic and Dynamic Voltage Restorer for Load Voltage Compensation. International Journal of Electrical Engineering \& Technology, 9(5), 2018, pp. 52-63.

[22] Shobha Rani Depuru, Muralidhar Mahankali and Navya Sree S, Design and Control of Standalone Solar Photovoltaic Powered Air-Cooling System, International Journal of Mechanical Engineering and Technology 8(7), 2017, pp. 1144- 1158.

[23] Shweta Dikshit, Solar Photovoltaic Generator with MPPT and Battery Storage. International Journal of Electrical Engineering \& Technology, 8(3), 2017, pp. 42-49 